\title{
Heidegger and the Question of Freedom in The Eumenides
}

\author{
${ }^{1}$ Bahee Hadaegh ${ }^{2}$ Mohsen Sohrabi \\ ${ }^{1}$ Assistant Professor, Shiraz University, Faculty of Letters and Humanities, Department of \\ Foreign Languages $\mathcal{E}$ Linguistics, Department of Foreign Language and Linguistics. Email: \\ bhadaegh@rose.shirazu.ac.ir \\ ${ }^{2}$ M.A. Graduate of Shiraz University, Department of Foreign Languages $\mathcal{E}$ Linguistics. E- \\ mail: soshiant.sohrabi@gmail.com
}

Received August 13, 2016; Revised November 20, 2016; Accepted December 22, 2016; Published January 14, 2017

\begin{abstract}
This paper first applies Heidegger's notion of in/authenticity to Orestes in Aeschylus' The Eumenides. The examination of authenticity is the departure point after which the question of freedom in this tragedy can be addressed mainly with Heidegger's Being and Time in view. It then discusses a possible interpretation of the Greek god Apollo which frees and yet entangles Orestes in his course of decisions, which is also a harbinger of a new historical era in which the mythos for the historical Dasein brings it to the destiny of people. Heidegger's understanding of tragedy brings the fate of historical man to the destiny of its people; therefore, in this reading of Aeschylus' The Eumenides the individual-as in early Heidegger - transforms into a historical gestalt which is meaningful only with a look into the possibilities of future.
\end{abstract}

Keywords: Authenticity, Being and Time, Freedom, History, The Eumenides

\section{Introduction}

The possibility of freedom as a theory and/or practice was always one of the main concerns of most philosophers and tragedians. It can be said that the core issue of tragedy is the struggle of the hero with its bizarre world to attain the conditions of the possibility of freedom with which and through which the hero and his heroic act is meaningful and justified. It can also be said that the tragic in tragedy is the decline of the hero in such struggles, when the possibility of freedom is made available but then freedom as such withdraws itself as ungraspable, belonging to man yet a belonging which manifests itself always in confrontation of man with himself.

Heidegger's Being and Time (1927) explicates the course of in/authentication of Dasein through which Dasein achieves freedom, takes a stand in a resolute decision in every situation or falls back into its world in an ambiguity identifiable with inauthenticity of the They. The question of freedom arises not only as an individual endeavor of Dasein, but also as the historical possibility for a people, as a commitment toward one's heritage and tradition and one's responsibility toward the possibility of future.

(C) AesthetixMS 2016. This Open Access article is published under a Creative Commons Attribution Non-Commercial 4.0 International License (http://creativecommons.org/licenses/by-nc/4.o/), which permits non-commercial re-use, distribution, and reproduction in any medium, provided the original work is properly cited. For citation use the DOI. 
Aeschylus' The Eumenides explores the forces that affect human choices and life, and their relations to the gods. Orestes is urged by Apollo to avenge his murdered father by killing his mother. Because Orestes was urged by Apollo to take action against his mother, the question of freedom arises here as the possibility of Dasein. The urge was not so much of a force, but rather as an urge to be free for one's world and not being free from it. Therefore, as a point of departure, this paper discusses the grounds for the Orestes' hesitation to take action or to resolutely accept his past, and the possibility of freedom and its grounds. It then deals with an opening into the future in which the possibility of founding of a new polis and new order is possible for the Greeks.

\section{The Question of Freedom in Being and Time}

The vulgar understanding of freedom understands it as the lack of restraining forces in which the possible loses its place to the actual, to the closes possibility which is offered to human being. Unlike this negative freedom Heidegger in Being and Time explicates the understanding of freedom as having a content, a Woraufhin (toward which), an understanding by which freedom is freedom for something. This positive conception of freedom is meaningful only in the historical context which bestows meaning to its direction and its demand. To gain access to the meaningful context of historicity of Dasein we must analyze the unifying phenomenon of Sorge in which the totality of the existential wholeness of Dasein becomes available.

Heidegger uses anxiety as "...the most far-reaching and most primordial possibilities of disclosure..."(Heidegger, 2010, 176) to provide the phenomenal basis for the explication of the wholeness of Dasein, Sorge. Because Dasein, initially and for the most part, has lost itself in the They it flees from itself and a potentiality-for-being that belongs to it. This flight has the uncanny character which is indefinite, the "Nothing which is at hand and present within the world.... the world has the character of complete insignificance [Unbedeutsamkeit]" (Heidegger, 180). Dasein is anxious about its authentic being-in-the-world since the world is its basic existential constitution. Anxiety primordially discloses Dasein in its possibilities, in "...its being toward its ownmost potentiality of being, that is, being free for the freedom of choosing and grasping itself" (Heidegger, 182). In anxiety, to fold it back on the structure of Sorge, Dasein is ahead-of-itself, always projectively thrown into the horizon of possibilities which it has their actualizations at its disposal. In this sense, Dasein transcends its present actuality into a future possibility which culminates the totality of the structural whole of Dasein; it is "beyond itself"(Heidegger, 185). This projection is the openness of Dasein which is delivered over to its thrown ground. This futureoriented movement of anxious Dasein opens the meaningfulness of being and beings in the thrown ground.

Anxiety also discloses Dasein as already-being-in-the-world. Anxious Dasein- in its open projection- is essentially delivered to its thrown ground as standing in the open, as coming down to a situation which opens a range of possibilities and meanings. This openness in the standing open of the future possibilities is the resoluteness of Dasein. Heidegger articulates resoluteness as "...the reticent projecting oneself upon one's ownmost being-guilty which is ready for anxiety" (Heidegger, 284). Anxiety also discloses Dasein as being finite. As thrown into the future, Dasein must take over the Nothing that resides in every thrown situation; this nothingness "...is like the silent and invisible frame that sustains the walling of the wall and the edges of the jug"(Beistegui, 2003, 232). The Nothing frees Dasein for its ownmost possibility of being its death. In this sense, future opens Dasein for its potentiality for being and closes it with its instant belonging to its own death; "... the future is itself closed and as such makes possible the resolute existential understanding of nullity"(Heidegger, 315). 
It is possible now to explicate the meaning of Sorge as temporality. Temporal Dasein is ahead-of-itself, that is, it is primarily its futural possibility rather than its present actuality; Dasein transcends it present situation. But also Dasein has always and already found itself in its thrown being, in its limit situations into which it is delivered over. This finding relates to Dasein as always and already having-been thrown in the present situation. Being-already-in the-world of Sorge here folds onto the having-been of temporality. Yet Dasein is its present thrown being in which beings present themselves to Dasein.

Heidegger has given priority to the ecstasy of future because it opens Dasein for its ownmost potentiality for being _death_ and also the openness into which Dasein has always delivered over. In this future-oriented movement Dasein comes back to itself, that is, a coming back into the Nothing and abyss of the thrown ground which always and already have-been. The future is always the repetition of the nullity that is constituent of the being of Dasein itself in every thrown ground. Therefore, Dasein comes to itself futurally from its past to the disclosing of meanings and possibilities of its present situation.

The Nothing which futurally arises from Dasein's past (having-been) in every thrown present brings Dasein to the anxiety of appropriating a future possibility for itself, an appropriation which is the fate of Dasein and the destiny of its people. The meaning for such appropriation which arises from the historicity of Dasein is provided by heritage and being itself which demands that "Resolute coming back to thrownness involves handing oneself over to traditional possibilities"(Heidegger, 365). Resoluteness is primordial freedom of Dasein because it authentically projects Dasein over to a heritage which is authentically thrown. Freedom is the fate of Dasein in which Dasein openly stands in the openness of thrown ground and appropriates a meaning, a content, and an upon-which which culminates in its ownmost possibility of death.

\section{The Question of Authenticity in The Eumenides}

The fact that most of tragedies begin only when a great deal of tragic were in action corresponds with the totality of the worldhood in which a character is thrown, we begin in the midst of tragic as we find the hero in the midst of its world. It is the finding of such Dasein which has itself "always already brought before itself... in a finding which comes not from a direct seeking, but from a fleeing"(Heidegger, 132). Therefore, in such finding Orestes is attuned for the condition of a choice which is provided by Apollo as demanding a respond to an urge which either opens a new historical mythos for the future or results in the demise of Orestes. The attuned being of Orestes as coming back from exile is filled with hesitations and fears. The ground upon which he has to project a possibility of himself as acting out a decision has not been obtained by him, but always given; and it is in the face of such given ground that authentic Dasein must appropriates a fate. The given is not the absolute determination of Dasein, but is as what the priestess of Apollo expresses "My prophecy is only as the god may guide"(Aeschylus, 33). It is the guiding into an openness into which the authentic Dasein must clear itself and its world in a meaningful projection; Heidegger calls this space the clearing, "a domain or structure which allows there to be things with properties and characteristics, or modes of beings....It is something like a space of possibilities"(Wrathall, 2005, 340). This guiding of Apollo is handed down to Orestes as the former "reads portentous signs/ and so clears out the houses others hold as well"(Aeschylus, 6364). These signs as the mysterious sending of being, which are meaning upon-which Dasein must

project itself; are the concealment of truth in signs and prophecies and unconcealment of Apollo as the site for providing an opening and clearing. 
In every unconcealing there occurs a corresponding concealing which may finally contribute to the tragic sense in tragedy; in other words, tragic must always rest in the concealing of beings and meaning. That is why Orestes asks Apollo "learn also what it is not to neglect. None can mistrust your power to do good, if you will"(Aeschylus, 8687). The neglect of gods who provide the thrown ground of Dasein is not so much that they conceal the meaning toward which Dasein must project itself, but rather the neglect is to show itself in withdrawing itself, to conceal the openness of the open, and consequently the mistrust is due to this dual-opposition character of being. It is this withdrawing character of the gods and being that Heidegger claims that every truth is a robbery. This robbery is put by The Furies; "Shame, son of Zeus! Robber is all you are"(Aeschylus 149). This robbery expropriates the familiar of the world.

In The Eumenides, in being anxious, Orestes must anxiously disclose the future course of events in an active sense, in a way in which he directly participates in the total narration of his being. Unlike Oedipus whose search for truth always leads him to the final stages of his actualization, Orestes escapes from such possibility. Because anxiety brings Dasein to the null and nothing of its thrown ground it can relate to death as coming from nothing and nowhere. But if this anxious encounter with the world and the possible in such world falls back to the world and identifies itself with objectively present within the world, then what is experienced is transformed into fear of the world; "The absorption of Dasein in the they and in the "world" taken care of reveals something like a flight of Dasein from itself as an authentic potentiality for being itself'(Heidegger, 178). The world makes available for Dasein to understand itself and the world it is in. Such a world can entangle Dasein by producing ambiguities and nearest possibilities against which"... thinking has to struggle against the inborn tendency of man to lose himself to the world, to ... his own mode of existence which blocks the very access to its central concern, i.e., the meaning of being..."(Ruin, 2008, 279).

But what encourages Dasein to fall back into its world? In absorption in the world Dasein turns away from something which is yet disclosed in the there of the world. It is "...the possibility of things at hand in general, that is, the world itself'(Heidegger, 181). The insignificance of the world arises from the irrelevance of things in their context or even lack of such contextual ground; therefore, possibility as the potentiality of Dasein merges also into insignificance, it becomes oppressive. What is made available for Orestes is the choice of matricide, what is his response to such a call, what is his stand against such an urge marks off the course of authentication of Orestes. To the examination of "urge" Heidegger adheres that "It is "toward at any cost." Urge seeks to crowd out other possibilities," it a way in which it" can outrun one's actual attunement and understanding"(Heidegger, 189).

The urging by Apollo is the leading for the possibility and condition of a response which is resolutely reticent and ready for anxiety. The urge or leap which Apollo opens for Orestes is the prophetic condition of grasping his ownmost potentiality-of-being and being free for such a choice; it is "When a god brings his or her energies to bear on something, the god changes the force or kind of its affective character"(Spinosa, 2000, 219). But Apollo as the look of the look is not present as the objectively present; "To be is to be present, but being present itself always a "luminous self-concealing"...concealing itself behind the being (Seiendes) that it illuminates"(Dahlstorm, 2011, 141). This urge can be compared to the crossroad in which Oedipus was called for a choice. Taken a road and not the other opens for Oedipus what lays ahead of him, what is a possibility which belongs to Oedipus wandering that road.

In responding to such a call (urge) Orestes is led into an opening in and through which he becomes free for death in anxiously disclosing the world as the unhomely of the home, the 
uncanny of the habited world is revealed. Therefore, Dasein, in the how of its there, is individuated, distinguished from the homely of the They. Inauthentic Dasein does not found its world through authentic disclosure, but rather it is "... tempted to interpret its situation as grounded in the world" and forgets that itself is "the futural temporalizing disclosure in and through which the world is manifested"(Ruin, 280).

In being-ahead-of -itself Orestes takes care of the world not in a way that such disclosing and taking care contribute to the totality of the narration of his being. In comparing Orestes' disclosure with that of Oedipus it is important to note that every phenomena that Oedipus face, the temple of Delphi, the crossroad, the Sphinx, and the plague contribute to the futural being of Oedipus as he is actively participating in the direction and demand of every life experience. Unlike Oedipus, Orestes takes care of the world not so as to genuinely disclose it but only to have known and experienced the immediate relevance of the world and the objectively present. In being-ahead-of-itself Orestes does not project a genuine understanding which frees beings in their truth, but rather projection and understanding only pertains to the possibility of acquittal of his crime. Heidegger calls the temporality of inauthentic being-ahead-of-oneself expecting which "...is not only an occasional looking away from the possible to its possible actualization. ...it is for its reality that what is expected is expected"(Heidegger, 251).

In being-already-in-the-world authentic Dasein understandingly projects itself in a submissive openness to the nullity of the thrown ground. Authentic Dasein frees itself for the opening that is made available by the ab-ground or abyss of the thrownness. Unlike Oedipus who is "free for its most extreme possibility of existence"(Heidegger, 290), Orestes is hesitant and avoidant. His being-in-the-world modified by the exile he has come from and hence being an "outlander"(Aeschylus, 202). The "wanderer"(Aeschylus, 93) that he is correlates with his "godless"(Aeschylus, 151) being in the world. Since gods reside in the polis, the godless wanderer is without a house; it is the house that shelters him and the house that negates him. So much like the Antigone who was cast out of the city for the laws of the house, Orestes too suffered the same fate. Elden explains this negation as: "[hypsipolis apolis]..."he and his city rise high-but the city casts out"'(2000, 411). The Furies also declares the estrangement of tragic Dasein to its house and city, it is to be casted in the unhomely of the home, "He falls, and does not know in the daze of his folly. ...his house lies under fog that glooms "(Aeschylus, 377-3780). Dasein must repeat the nullity of its past thrownness in a submissive projection which brings Dasein into the open of the future possibilities. As an example; Oedipus is thrown into Thebes, he is then casted out of his house and city as the primary null ground of his being. Then in the development of tragedy he is again casted out of his home and city from Corinth only to come back to his primary null and nothing of his being. The return of Oedipus to Thebes signifies an appropriation to the nothing of his ab-ground in always and already having repeated it.

Heidegger also examines that an inauthentic Dasein in temporalizing its being-in-theworld forgets such abyss and nothing which always and already goes behind and before Dasein. In making-present his present situation, in a direction which is not dictated by a giving-up of oneself for being anxiously free to stand in the open, Orestes forgets that the nothing is the primary home of Dasein. Such "resolve" is the constant standing open and free for the revelation of being and truth in every situation in which Dasein is delivered over; "[the primordial truth of existence] is disclosed only in a free act of resolve that has not been determined beforehand, but is open to the possibility of such determination"(Heidegger, 294).

In interrogating the shepherd that has delivered him out of the city, Oedipus is already resolved itself to the situation in which the truth of his being has become available for him. This 
search and questioning is the anxiously and resolutely being free of Oedipus which finally brings him to the opening in which he clears himself and the truth of himself. But for Orestes who is not free for his world the question "But was the bloodshed right or not? (Aeschylus, 612)" marks the entanglement and hesitation which is freed for him in his situation in which he resolutely does not project.

\section{The Question of Freedom and History}

Through anticipatory resoluteness Dasein achieves totality and transparency in a way that frees Dasein to be open in standing in the open provided by thrownness. But such freedom is meaningful in the wider context of history and heritage in which authentic Dasein in a coresponding mode completes itself. Nichols explains that "... this very freedom is a "delivering over" to one's fateful destiny. Freedom "is," therefore, only insofar as it is historically determined"(200o, 12-13).

But how such conception of freedom relates to history and historicity of Dasein? Freedom is standing open in the revelation of being and letting beings be in the way they are in their own truth. But this standing open is the authentic projection of Dasein into the openness of thrownness which releases beings in their truth. The meaning which is made available for such projections is the sending of being itself. Heidegger believes that "Beings "have" meaning only because... they become intelligible in the project of that being [Sein]... The primary project of the understanding of being "gives" meaning"(Heidegger, 310). Because being sends the meaning for every projection and since being is time the meaning and truth must be historical. Nichols adds "Being is time (i.e., the meaning (Sinn) of being (Sein) is revealed to be primordial time)... Because being "is" time, beings are revealed not "in time," but "from time itself"(2000, 8).

But the freedom that is discussed in Being and Time is attained by the resolute Dasein in the authentic opening opened by heritage and tradition. Dasein is ahead-of-itself, it transcends it present actuality toward its future possibility so that Dasein becomes free for the ground that thrownness introduces to it. Therefore, "Freedom is a freedom for the ground"(Ruin, 282). But then in this discussion freedom is not itself the ground, but to be resolutely free to stand in the open respondingly. Freedom in this explication is what "possesses man"(Ruin, 284). Since freedom brings Dasein to the possibility of its future, and since freedom then becomes the ground for such delivering of Dasein to its potentiality, it becomes "the ground of possibility of man"(Ruin, 285). Evidently there is a turn in explication of the phenomenon of freedom in the philosophy of Heidegger. First freedom is the harbinger of Dasein to stand resolutely in the opening of the future, then this movement itself becomes the very ground for being open in standing in the opening. Ruin suggests that with this interpretation, freedom becomes more primordial than Dasein. That "freedom does not appear as "a property of man," but... [rather] man is the property of freedom, the essence of man is grounded in freedom, as itself a fundamental determination of being"(Ruin,287). It is in belonging to the world as that which authentic Dasein worlds that Dasein can belong to freedom. Furthermore, because Dasein essentially and existentially is always and already thrown, it is equally made possible in its belonging to the freedom. What Ruin expresses as belonging to being can also be said about belonging to freedom in a sense that "... we are that to which we also belong. But this belonging is only actualized to the extent that we confirm it (bezeugen), which is what happens in Dasein"(Ruin, 289).

To fold our discussion of freedom back on the delineation of historicity of Being and Time makes clear that such belonging to freedom is first addressed and achieved in the phenomenon of 
resoluteness. Heidegger discusses that "The certainty of resolution means keeping oneself free for the possibility of taking it back..."(Heidegger, 294). Since this resolution finds it meaning in the context of heritage and history it must repeat itself unto the fate of Dasein and the destiny of a community. Resoluteness "...becomes the repetition ... of a possibility of existence that has been handed down"(Heidegger, 367). In applying this conception of freedom in the context of The Eumenides not only freedom as a demand is feared, but also the possibility of such demand is nulled and closed. Clytemnestra points to this concealing as "eyes illuminate the sleeping brain, but in the daylight man's future cannot be seen"(Aeschylus, 104-105). It is being itself and the projected meaning of being that withdraws itself in every thrown ground of Orestes. Since Orestes does not resolutely project itself into the opening of the future, this concealing has doubled itself, first as concealing and second as ignorance of such concealment. It was due to this interplay of un/concealing that Apollo urged Orestes to open and shelter this horizon in its essential oppositional character.

The tragic in this tragedy can be the violence which such an urge provokes and demands. This violence is expressed by The Furies addressing Apollo that "he made man's way across the place of the ways of gods/ and blighted age-old distributions of power"(Aeschylus, 171-172). Apollo's temple is the horizon through which the direction of the possibility of authentication is first made available through sings and riddles, it is the godly site from which possible paths of the future of Dasein is distributed. The temple is the gathering which, so much like Dasein, is the place of the happening of truth; it "is a location for a historical metaxy of presencing between the past (thrownness) and future (projection)"(Nichols, 5). Like Oedipus who is essentially and existentially the sheltering of the oppositions _ he is the son and the husband, the savior and the sickness, the native and the exile_ the temple as a sheltering is the distribution of paths from which the salvation or damnation of a polis may follow, and it is an intersection in which the past and future of Dasein meets together; a sheltering because "to be a human is to be an unfolding event or happening"(Guignon, 2013, 120). This metaxy is the Untergang of the tragic hero. According to his discussion Untergang is "a "going-between," echoing ... that the Da-sein of historical man is a Zwischen-fall, an (unforeseen) "in-cident", or literally, a "falling-between"'(Gall, 2003, 179) by which the past and future are gathered in the temporality of present.

Orestes has fallen between Apollo and The Furies, exile and the polis, old and new laws, and younger and older gods. Since Untergang is a falling-between it reveals the decline of tragic hero as falling into "an acknowledgment of the removal of reasons or grounds (Ab-grund)"(Gall, 181). It is a falling which is characterized by an addressing force and temptation which absorbs Dasein to its world. This falling-between in going down is stated in a choral song by the Furies "save you going down, forgotten"(Heidegger, 300).

\section{Conclusion: Mythos of Dasein of Historical Man}

One of the main forces which weaves and gathers historical Dasein in a unifying gestalt, in which the fate of a Dasein is interrelated to that of its community, is myth. The tragedies of Aeschylus founds a myth for the Greeks by and through which the community is called for a response and a decision. It is through the violence that is essential to tragedy that historical Dasein faces a new opening and ordering of the future. It is such tragedy and myth which as an exemplary entity "... lies at the very heart of the community. It is the narrative through which the community can be identified, articulated, communicated and hence perpetuated" (Beistegui, 1991, 29). 
The heritage and tradition that is handed down in thrown being of Dasein has a force by which the course of future for Dasein and its community is laid in front and into questioning. It is through a thrust that such heritage makes available for its community to open a new beginning in their history. This thrusting force can be provided by art and myth. Tragedy as one of the most significant artworks of Greeks is the site in which past and future are put into question in a new light. Gover believes that "The tragic for Heidegger names the movement according to which the history of being paradoxically discloses itself through a kind of withdrawal $(2009,41)$." What is opened by tragedies of Greeks to its community is the possibility of a new understanding of being and man himself through a different ontological glass. Tragedies of Aeschylus and their thrust "...sketch out the possible ways of understanding victory and defeat, blessing and curse, and they thereby call for a choice from the people as to how they will understand their lives in the light of these works"; they are also freedom's directives and demanding ""with which all decision complies"'(Guignon, 2000, 99).

The tragedy may open a new era in social life of historical Dasein, in a way that the individual must essentially merge from and confirm to the community as belonging to a current which bestows meaning and possibility with a new aspect. It is through the work of art, tragedy or myth, that Dasein in correspondence with its community worlds. It is a decision that being bestows and a decision which requires response from Dasein:

Being, the occurrence of world, is "epochal" in its essence. When an epoch comes to pass, this means that "Being has taken on an essence," that it has bestowed "an essence upon thought and thus upon man..." (Bartky, 214)

\section{Works cited}

Aeschylus. (1953). Complete Greek Tragedies. (ed. Grene, D. \& Lattimore, R.). Chicago: The University of Chicago Press.

Bartky, S. L. (2011). Heidegger and the Modes of World-Disclosure. Philosophy and Phenomenological Research, 40 (2), 212-136.

Beistegui, M. de. (2003). Transformation of the Sense of Dasein in Heidegger's Beitrage zur Philosophie (vom Ereigenis). Research in Phenomenology, (33), 221-246.

--- (1991). Heidegger's Mythocentrism. Research in Phenomenology, 21 (1), 21-35.

Dahlstorm, D. O. (2011). Being at the Beginning: Heidegger's Interpretation of Heraclitus. Interpreting Heidegger: Critical Essays (ed. Dahlstorm. D. O.). Cambridge: Cambridge University Press.

Elden, S. (2000). Rethinking the Polis: Implications of Heidegger's Questioning the Political. Political Geography (19), 407-422.

Gall, R. S. (2003). Interrupting speculation: The thinking of Heidegger and Greek tragedy. Continental Philosophy Review (36), 177-194.

Gover, Karen. (2009). Tragedy and Metaphysics in Heidegger's "The Anaximander Fragment". Journal of British Society for Phenomenology, 40 (1), 37-53.

Guignon, C. (2013). Becoming a Self: The Role of Authenticity in Being and Time. The Cambridge Companion to Heidegger's Being and Time (ed. Wrathall, M. A.). Cambridge: Cambridge University Press. 
$61 \mid$ Heidegger and the Question of Freedom in The Eumenides

--- (200o). Philosophy and Authenticity: Heidegger's Search for a Ground for Philosophizing. Essays in Honor of Hubert L. Dreyfus: Heidegger, Authenticity, and Modernity (ed. Mark Wrathall, M. A. \& Malpas, J.), 1. 79-102.

Heidegger, M. (2010). Being and Time (trans. Joan Stambaugh). New York: State University of New York.

Nichols, C. M. (200o). Primordial Freedom: The Authentic Truth of Dasein in Heidegger's 'Being and Time'. Thinking Fundamentals, 9, 1-14.

Ruin, H. (2008). The Destiny of Freedom in Heidegger. Continental Philosophical Review, (41), 277-299.

Spinosa, C. (200o). Heidegger on Living Gods. Essays in Honor of Hubert L. Dreyfus: Heidegger, Coping, and Cognitive Science (ed. Mark Wrathall, M. A. \& Malpas, J.), 2, 209-228.

Wrathall, M. A. (2005). Unconcealment. A Companion to Heidegger (ed. Dreyfus, H. L. \& Wrathall, M. A.). UK: Blackwell Publishing Ltd, 337-357. 